\title{
Permian Diptera from Warner's Bay, N.S.W.
}

\author{
By Dr. R. J. TILLYard, F.R.S.
}

$\mathrm{O}^{\mathrm{F}}$ the myriads of species of insects which swarm upon this earth, none is of such absorbing interest to mankind in general as the two-winged flies grouped together in the great order Diptera. This order is, by common consent, admitted to be one of the most highly specialised within the class, if not actually the most highly specialised of all. Yet, while no undoubted fossils of the order Lepidoptera, for example, are known older than the early Tertiary, definite, though somewhat obscure, dipterous types are known from the European Lias. We know, however, that the Lepidoptera must have existed for millions of years as obscure and very small types similar to Micropteryx and its allies, and that these in their turn had a common origin with the Caddis-flies or order Trichoptera. Ancient representatives of this latter order also occur so far back as the Lias, and I have previously given reasons why the common stem of the two orders Lepidoptera and Trichoptera must be regarded as having arisen from an extinct side-branch of the older order of Scorpion-flies or Mecoptera, which goes back, geologically, almost unchanged to the Lower Permian and probably also to the Upper Carboniferous.

More recent researches into the origin of the Diptera indicate clearly two outstanding facts; $(a)$ that they are, of all existing orders, the most closely allied to the Mecoptera, and $(b)$ that they must have had origin from the Mecoptera by way of a type, or types, closely resembling the hypothetical common ancestor of the Lepidoptera and Trichoptera, but retaining the markedly mecopterous character of an unbranched first cubitus in the forewing, whereas this vein is always branched in the other two orders. A number of forms clearly belonging to this ancestral group, which I have elsewhere called the order Paratrichoptera, but which Dr. Crampton prefers to call Protodiptera, were described by me from the Upper Trias of Ipswich, Queensland (Proc. Linn. Soc. N.S.W., p. $199 ; 1919)$. Later on, through the discovery of the older insect fauna of Belmont, N.S.W., of Upper Permian age, these forms were linked directly with the true Mecoptera by way of the two fossil genera Belmontia and Parabelmontia, which I placed in the new order Paramecoptera (Proc. Linn. Soc. N.S.W., p. $234 ; 1919$; and p. $286 ; 1922)$.

Fossil-hunting at Belmont has always been a very arduous task, because of the hardness of the rock and the extreme rarity of the fossils. A good average would be about one wing for three days' hard labour! Under such conditions it never seemed likely that a full knowledge of the Upper Permian insect fauna could be obtained. The late Mr. John Mitchell, who discovered these beds, had always in mind the possibility of finding an extension of them somewhere around the shores of Lake Macquarie. With the aid of Mr. T. H. Pincombe, he succeeded in exploring a number of localities with the same geological horizon, and finally they opened up the rich fauna of Warner's Bay, on the shores of the lake above mentioned.

The Upper Permian of Warner's Bay has now yielded several hundred specimens, most of which still await description. Apart from abundant Homoptera and two problematical remains of Odonata, the fauna is entirely holometabolous, consisting of the dominant order Mecoptera and the orders Paramecoptera, Neuroptera Planipennia, Protocoleoptera, and Coleoptera. The extensive representation of the order Mecoptera has brought to light so many new types that it is now found advisable to include the orders
Paramecoptera and Paratrichoptera as suborders of that order, by means of a very slight extension of its accepted definition. With this extension accepted, it would be scientifically correct to state that the three orders Diptera, Trichoptera, and Lepidoptera have been evolved from mecopterous ancestors.

The most interesting fact about the Warner's Bay Beds, as contrasted with the neighbouring Belmont Beds of the same age, is the abundance of very small insects. This is particularly noticeable in the Homop. tera and Mecoptera. In the latter order there are large numbers of tiny, fly-like Mecoptera, closely allied to the existing Australian family Nannochoristidæ. Some of these are practically complete specimens, and the more slender of them appear to have had hindwings in various stages of reduction, though their habit of dying with all four wings closely folded together makes the working out of the hindwing a very difficult task.

Bearing in mind the fact that four-winged Paratrichoptera are known to have lived in Australia right up to Upper Triassic times, while the oldest known true Diptera are Liassic, it did not seem very probable

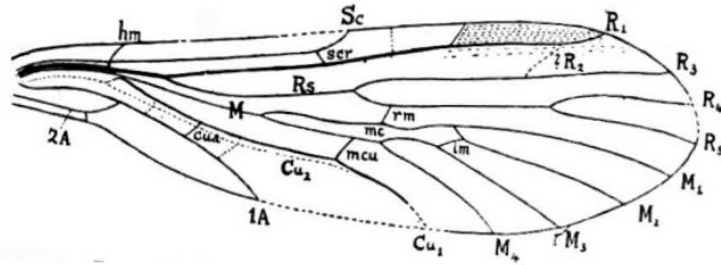

FIG. 1.-Permotipula patricia n.g. et sp. Forewing. Length $5 \mathrm{~mm}$. Upper Permian of Warner's Bay, N.S.W. Discovered by Rev. A. J. Barrett, 1928.

that we should ever discover true Diptera at Warner's Bay. But I have had the possibility in mind for some years, remembering that Protocoleoptera are found alongside true Coleoptera in the same beds, and Protodonata alongside true Odonata in the Lower Permian of Kansas. Every small Mecopteron has been carefully studied in the hope of finding something more definitely dipterous than any hitherto known. But, until quite recently, the search was unavailing.

When I returned to Australia in October last, my friend the Rev. A. J. Barrett, who had become interested in the Warner's Bay Beds, sent me a small parcel of fossil insects which he had found there. Looking through these, I found the distal two-thirds of a small wing which seemed to me so obviously dipterous that I at once proceeded to study it in detail. To my great joy $\mathbf{I}$ found that both obverse and reverse impressions had been saved, and that in one of these the basal portion of the wing was covered by a small piece of rock. It is a risky matter to attempt to uncover hidden portions of fossils in this cherty shale; but I took the risk. A lucky stroke removed the overlying piece, and succeeded in exposing the complete wing, with only minor damage. To my astonishment, not only was this found to be truly dipterous, with an unexpectedly petiolate basal portion, but it must also be definitely classified as Tipuloid, and distinctly more advanced than such living forms as the Tanyderidæ, which have retained the original four-branched radial sector $(R s)$.

Fig. 1 shows this remarkable wing, which is just $5 \mathrm{~mm}$. in length. The missing portions of the costa, apex, and posterior margin, and of the apical part of the first cubitus, are indicated by broken lines; 
otherwise the wing is complete. The wing is of the greatest interest, because any student of venation would certainly classify it as dipterous and nothing else, and yet we do not know whether the insect to which it belonged had four wings or only two! Also, it is the oldest known dipterous type of wing by many millions of years.

To facilitate discussion, it would be advisable to name the wing at once. At Mr. Barrett's request, I name it after my wife, as Permotipula patricia n.g. et sp. The wing must be classified in the superfamily Tipuloidea, in a new family Permotipulidæ characterised by the slight degree of petiolation, the short $2 A$ and the elongate median cell $(m c)$, and in a new genus Permotipula distinguished by the form of $S c$, the positions of $r m$ and $m c u$, the extreme narrowness and irregularity of $m e$, and the sessile origin of both median forks from that cell. A full analysis of the venational characters and a comparison with known archaic forms of Diptera will be published elsewhere. The figure itself is sufficient diagnosis of the species.
This discovery appears to indicate that the tendency towards lengthening and narrowing of the wings, which is marked enough to have been com. memorated in the very name of the ancestral order, Mecoptera, ran to two successful specialisations. The first of these, the family Bittacidæ, retained all four wings, and so remains classified to-day as a family within the Mecoptera. The second evolutionary effort, acting on much smaller and more insignificant types allied to the Nannochoristidæ, produced the true Tipuloid Diptera, or two-winged analogues of the Bittacidæ. From such small and obscure forms as the one now discovered, the great order Diptera must have originated, with all its multitude of new types, just as the even greater order Lepidoptera must also have originated from small and obscure types resembling Micropteryx and its allies. For a correct understanding of the larval forms of these two great orders, maggot and caterpillar alike, we must go back to the ancient polypod larva of the true Scorpionflies.

\section{The Department of Scientific and Industrial Research.}

A PERUSAL of the Report of the Department of A Scientific and Industrial Research for the year 1927-28 (Cmd. 3258. London: H.M.S.O.), which includes a summary review of the work carried out under the various research organisations of the Department during the year, will provide the reader with abundant evidence of the wide range of the activities and responsibilities of the Department. The position of the research associations formed under the ægis of the Department is discussed elsewhere in this issue (p. 749). The National Physical Laboratory and the Geological Survey have been for some years under the general direction and control of the Department; and there are between forty and fifty research boards and committees, dealing with such diverse subjects as chemistry, fabrics, engineering, metallurgy, physics, radiology, building, architectural acoustics, heating and ventilation, food, forest products, fuel, atmospheric pollution, national coal resources, water pollution, adhesives, dental investigations, gas cylinders, illumination, lubrication, and $\mathrm{X}$-rays. To attempt to give, in a reasonable allowance of space, a condensed compendium of what the report has to say on all, or even most, of these activities, is obviously impossible, and we must be content to select, more or less at random, some features of interest.

There are 36 pages devoted to a summary of the main features of the work of the nineteen research associations still in receipt of grant aid from the Department. The Wool Research Association has introduced this year a new woollen ring spinning frame which, it is claimed, is capable of producing two and a half times as much yarn per spindle as the standard frame, and of giving a superior yarn. It is the outcome of an exhaustive analysis by the latest scientific methods of the exact functions of every part of the existing 'Standard ' machine ; an analysis which showed clearly the directions in which simplicity could be effected without destroying practical efficiency. Reference is made to the new lead alloy introduced by the Non-Ferrous Metals Research Association as a result of investigations undertaken in co-operation with the Research Department, Woolwich. It has a strength, weight for weight, some 40 per cent greater than the ordinary commercial lead which is used for lead pipe, and, because of its freedom from the defect of a peculiar type of cracking, it is being used as a covering for electric cables. The remarkable, but not surprising, statement is made that " the Association has hitherto failed, in spite of many efforts, to arouse any interest in it among manufacturers of lead pipe and sheet". This is but another instance of the many that could be given to illustrate the lag between the completion of a research and the application of its results to large-scale industrial practice.

The report directs attention to the surprising statement in the inaugural address of the president of the Institution of Locomotive Engineers, in September 1927, that locomotive engineers have " not at their disposal any facilities for trying out experimental scientific research", and that there is no existing organisation in Great Britain which is available generally for the accurate testing of the performance and thermal efficiency of a locomotive. The Advisory Council, as the result of recent conferences on this subject, foreshadows the establishment of a national organisation for locomotive research.

On the subject of low temperature carbonisation the report states that "several processes are now being operated on a scale large enough to provide reliable data by which the possible limits of commercial success can be judged". A subsidiary company of the Gas Light and Coke Company, for example, is erecting plant to try out on a commercial scale the experimental retorts developed at the Fuel Research Station. Other investigations, connected with fuel research, to which brief reference is made, are those on metallurgical coke, which are being carried out by the Federation of Iron and Steel Manufacturers in co-operation with the Department; on the use of pulverised fuel in the mercantile marine ; and on the economical use of coal.

The Empire Marketing Board has provided a sum of $£ 18,500$ for the period up to Mar. 31, 1929, which has enabled the Director of Food Investigation to initiate a new programme of research on the preservation and transport of fish. Attention has been paid, in the first place, to those investigations likely to yield results capable of adoption by the existing fishing fleets, and, in particular, to an investigation into the possibility of landing in first-rate condition an increased proportion of the fish caught. "Preliminary investigations carried out during the summer of 1927 showed, rather unexpectedly, that the flesh of fish is not inherently of a highly perishable nature, but that, on the other hand, the natural rate of deterioration is profoundly affected by secondary environmental factors." Aberdeen has been selected 